\title{
ВПЛИВ ТЕХНОЛОГІЇ ОБРОБЛЕННЯ ПІДШИПНИКІВ ПОЛІГРАФІЧНИХ МАШИН НА ЯКІСТЬ ДРУКОВАНОЇ ПРОДУКЦІї
}

() А. П. Гавриш, д.т.н., професор, Т. А. Роїк, д.т.н., професор, О. О. Мельник, к.т.н., асистент,

Ю. Ю. Віцюк, к.т.н., асистент, НТУУ “КПІ» Київ, Україна

В данной статье рассмотрен метод магнитно-абразивной обработки подшипников скольжения из новых материалов для тяжелых условий эксплуатации полиграфических машин, его влияние на свойства рабочих поверхностей деталей трения и качество продукции полиграфии.

In this article the method of magnetic-abrasive finishing of new materials sliding bearings for heavy exploitation conditions of polygraph machines, its influence for working surfaces properties of friction details and printing production's quality have been presented.

\section{Постановка проблеми}

Успішне функціонування підприємства будь-якої галузі промисловості, зокрема, поліграфічної, в умовах сучасної ринкової економіки вимагає виготовлення продукції не тільки високої якості, але і виробництво цієї продукції у стислі терміни. Тобто перед підприємствами постає завдання виготовлення продукції «сьогодні на завтра».

Досягти таких результатів можна декількома шляхами, наприклад, розширенням кількості обладнання. Проте такий шлях розв'язання проблеми не завжди виправданий, оскільки придбання нового обладнання на сьогодні $є$ достатньо дорогим. Іншим шляхом є збільшення потужностей машин, зростання швидкостей руху виконавчих і допоміжних механізмів задля нарощування випуску обсягів продукції за одиницю часу. Цей шлях вимагає підвищення вимог до надійності й довговічності роботи обладнання, зокрема, високошвидкісних машин та обладнання.

На сьогоднішній день у високошвидкісних поліграфічних машинах застосовують ряд підшипників ковзання на основі бронзи, заліза, мідних та нікелевих сплавів в залежності від умов роботи.

Проте на сьогодні підшипники, що застосовуються, мають невеликий термін служби внаслідок швидкого зносу, що пов'язано з важкими умовами їх роботи - високі швидкості обертання (до 600 об./хв.), навантаження до 4,0 МПа, агресивне середовище - повітря i, нарешті, абсолютна неефек- 
тивність змащувальних мастил, які викидаються із зони тертя відцентровими силами при високих швидкостях обертання.

Так, наприклад, за даними Державного підприємства Преси України в друкарських машинах навіть 2004-2005 рр. випуску встановлені підшипники ковзання працюють лише від півроку до одного, після чого виникає необхідність їх заміни [1]. Це пов'язано не тільки з недосконалістю технологій їх виготовлення, але й 3 відсутністю цілеспрямованих заходів формування якості їх робочих поверхонь, які сприймають основне експлуатаційне навантаження, завдяки застосуванню нових технологій фінішного оброблення.

Безпосередній вплив на зносостійкість підшипників поліграфічного обладнання чинить технологія механічного оброблення контактуючих поверхонь та одержані при цьому їх параметри якості, які забезпечуються саме на фінішних операціях, зокрема, шорсткість робочих поверхонь.

До того ж саме від шорсткості робочих поверхонь залежать кінцеві фізичні властивості поверхневого шару високошвидкісних підшипників ковзання поліграфічних машин, а відтак, і якість друкарської продукції. Тому тема дослідження $€$ актуальною і потребує виконання комплексу теоретичних та експериментальних задач.

\section{Мета роботи}

Метою роботи є встановлення впливу методу магнітно-аб- разивного оброблення підшипників ковзання з нових матеріалів на основі нікелевого сплаву ЭИ 929- $\mathrm{CaF}_{2}$ та на основі міді ДН5МЗКФ9 для важких умов експлуатації поліграфічних машин, його вплив на властивості робочих поверхонь деталей тертя та якість продукції друкарства.

\section{Результати проведених досліджень}

Об'єктом дослідження був процес формування параметрів якості поверхонь підшипників ковзання, призначених для важких умов експлуатації, що використовуються в поліграфічній високошвидкісній техніці, при застосуванні нових методів їх магнітно-абразивного оброблення.

Предметом були високошвидкісні композиційні підшипники ковзання на основі нікелевого сплаву ЭИ 929- $\mathrm{CaF}_{2}$ для роботи при швидкостях обертання до 600 об./хв. та на основі міді ДН5МЗКФ9 для роботи при швидкостях обертання до 400 об./хв.

Задачами досліджень було не тільки збільшення строку служби таких деталей при роботі у важконавантажених умовах експлуатації - високі швидкості обертання та навантаження до 4,0 МПа, але й підвищення якості друкованої продукції при застосуванні таких деталей замість традиційних.

Постійна тенденція покращання якості, надійності і довговічності продукції поліграфічної промисловості вимагає досягнення на чистових операціях механічної оброблення 
вузлів тертя високих експлуатаційних властивостей оброблених поверхонь. Одним з важливих показників якості $\epsilon$ шорсткість оброблених поверхонь, яка впливає на величину опорної поверхні контактуючих деталей, тому визначає довговічність і надійність їх роботи. Здебільшого під час механічної обробки чистова операція виконується шліфуванням абразивними кругами.

При фінішній обробці необхідно забезпечити утворення форми і розмірів виробу і при цьому надати йому необхідних фізико-механічних властивостей за мінімальними втратами і відходами, за мінімально можливій кількості операцій, з максимальною продуктивністю [1]. Традиційні методи механічної обробки (шліфування абразивними кругами) не завжди забезпечують отримання стабільного стану обробленої поверхні, що пов'язане з принциповою особливістю цих методів - жорстким закріпленням абразивного зерна.

Одним 3 перспективних та ефективних методів фінішної обробки є метод оброблення деталей в магнітному полі [24] феромагнітними порошками, метод - магнітно-абразивне оброблення (МАО). Даний метод дозволяє не тільки покращити якість поверхонь, фізико-механічні характеристики, тобто зміцнення поверхневого шару матеріалу, але і скорочує час оброблення, забезпечує високу продуктивність, низьку собівартість, простоту технології, мінімізацію людської праці, i, що $€$ надзвичайно важливим обумовлює порівняно малі температури в зоні оброблення та сприяє підвищенню експлуатаційних властивостей оброблених деталей. МАО дозволяє отримати високі параметри шорсткості робочих поверхонь, що $€$ визначальним фактором для роботи високошвидкісних підшипників друкарських машин.

На рис. 1 зображено діаграму, що відображає тенденцію розвитку технологій МАО по країнам світу за період кінця XXI століття.

Як видно з рис. 1, найбільшого розвитку МАО набула у Китаї, Японії, Південній Кореї, Білорусії, Росії та США. Ці дані свідчать про перспективність обраного методу обробки.

Застосування методу МАO при фінішному обробленні робочих поверхонь досліджуваних деталей забезпечило високу якість їх робочих поверхонь. Було встановлено, що нові розроблені режими оброблення забезпечують підвищення параметрів якості поверхонь у 1,5-2 рази в порівнянні із традиційними способами. Насамперед, показники шорсткості робочих поверхонь досліджуваних підшипників ковзання становили $\mathrm{Ra}=0,05-0,08$ мкм.

Слід зазначити, що умови експлуатації циліндрів та валів друкарських машин характеризуються високими швидкостями обертання та підвищеними навантаженнями, що супроводжуються періодичними зупинками для технологічних потреб. 


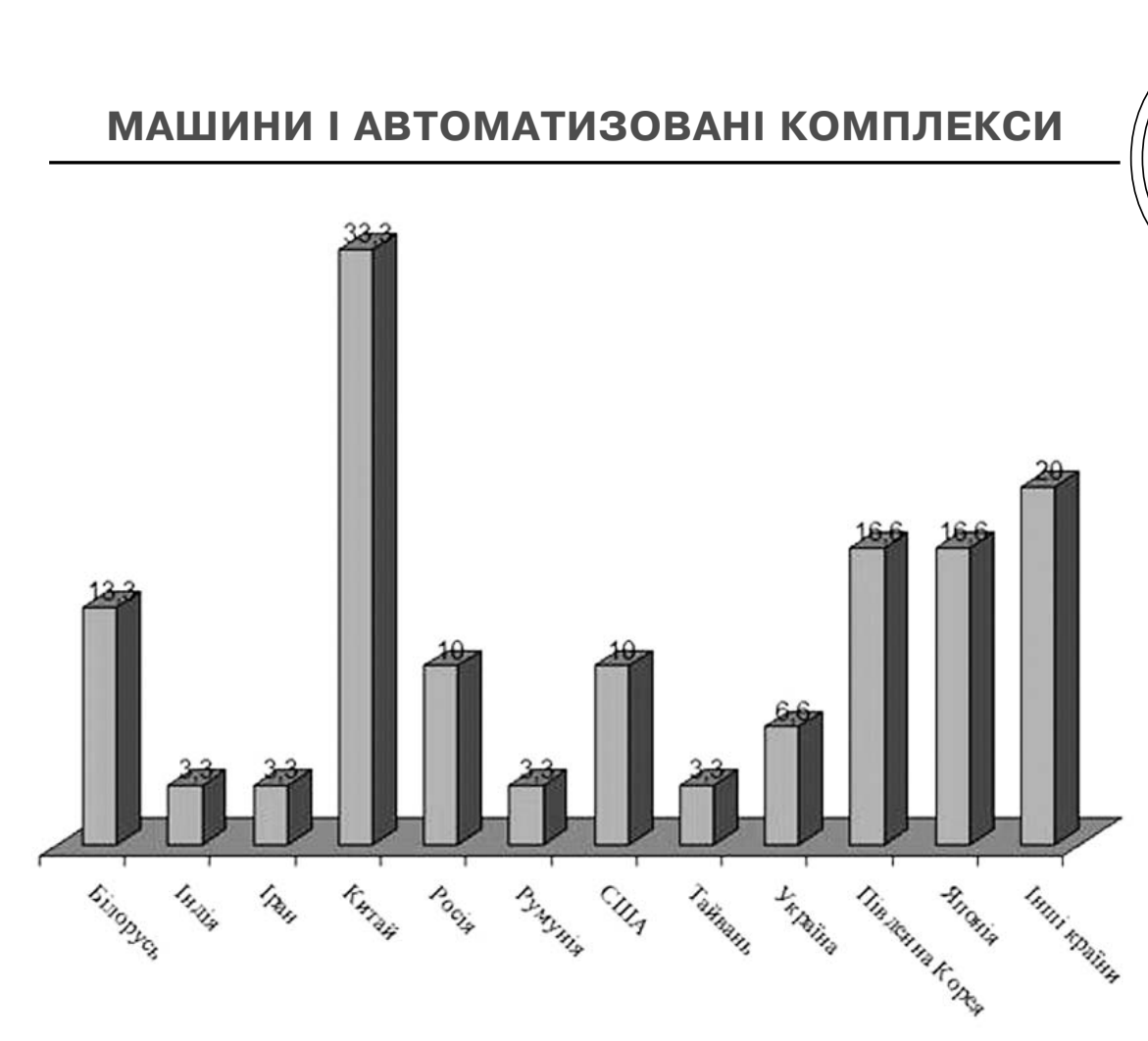

Рис. 1. Розвиток магнітно-абразивних технологій в світі

Негативним явищем функціонування таких механізмів $€$ биття валів, яке пов'язано з нестабільністю роботи з'єднань деталей тертя, зокрема, з незадовільною роботою працюючих 3 рідким мастилом існуючих бронзових, бабітових, залізних та нікелевих підшипників, що викликає їх інтенсивний знос, а відтак, і зниження якості відбитків, та збільшує обсяги браку друкованої продукції.

Тому вельми важливим було визначити вплив встановлених у вузли друкарських машин деталей тертя - нових композитних самозмащувальних підшипників на основі нікелевого сплаву ЭИ $929-\mathrm{CaF}_{2}$ та на основі міді ДН5МЗКФ9, оброблених за новими технологіями надтонкого абразивного оброблення, зокрема, магнітно-абразивним об- робленням, на якість друкованої продукції. Для цього застосовували візуальні та інструментальні методи.

Дослідження оптичної густини $\left(D_{\text {відб }}\right)$ проводили при оцінці відбитків, що були надруковані на шестифарбовій машині KBA Rapida-105 на крейдованому папері масою $115 \mathrm{r} / \mathrm{M}^{2}$ та на офсетному папері масою $80 г / \mathrm{M}^{2} 3$ використанням блакитної, пурпурної, жовтої та чорної фарб «Rapida FW 7020».

Тестовий наклад у кількості 200 аркушів паперу був надрукований без зупинок. Візуально проводився контроль всіх отриманих відбитків. Для інструментального контролю відбирали 3 партії по 25 аркушів (з початку, з середини та 3 кінця). 3 цих партій відбирали по три аркуші, які підлягали вимірюванню. Ви- 
мірювання оптичної густини здійснювали за допомогою денситометра FAG Vipdens C2.

На рис. 2, 3 зображено результати вимірювання оптичної густини плашки при роботі друкарської машини KBA Rapida-105 з встановленими у вузли базовими литими підшипниками з бронзи Бр.ОЦС 6-6-3 та підшипниками на основі нікелевого сплаву ЭИ 929- $\mathrm{CaF}_{2}$ та на основі міді ДН5МЗКФ9, оброблених за новими технологіями [3, 4] надтонкого абразивного оброблення відповідно.

Як видно з рис. 2, 3 розподіл оптичної густини на відбитках при застосуванні у друкарській машині самозмащувальних підшипників на основі нікелевого сплаву ЭИ 929- $\mathrm{CaF}_{2}$ та на основі міді ДН5МЗКФ9, оброблених за новими технологіями надтонкого абразивного оброблення, $є$ досить рівномірним та практично не відрізняється від розподілу оптичної густини при застосуванні у вузлах машини базових литих підшипників з бронзи Бр.ОЦС 6-6-3 і знаходиться в нормованих межах для крейдованого паперу чорної фарби 1,5-1,65 Б; кольорових фарб 0,9-1,5 Б. Видно, що розкид середнього значення оптичної густити на всіх відбитках незначний, в межах $\pm 0,1$ Б, відповідає нормованим значенням і $€$ візуально непомітним для людини. Візуально ж відображається на якості друку неперервна зміна оптичної густини $\left(D_{\text {відб }}\right)$ від одного краю відбитку до іншого у межах 3 \%.

Прямолінійний характер, побудованих залежностей (рис. 2, 3) дає підстави зробити висновок про рівномірний розподіл фарбового шару по всій площі відбитків, надрукованих при встановленні у друкарську машину KBA Rapida-105 деталей тертя на основі нікелевого сплаву ЭИ 929- $\mathrm{CaF}_{2}$ та на основі міді ДН5МЗКФ9, оброблених за новими технологіями надтонкого абразивного оброблення.

При подальшому оцінюванні якості друкарської продукції за розтискуванням та суміщенням фарб було виявлено, що при застосуванні базових литих підшипників з бронзи Бр.ОЦС 6-6-3, що працюють з рідким мастилом, спостерігається нерівномірність суміщення фарб та підвищення розтискування, що пов'язано з явищами збільшення биття валів в наслідок спрацьовування підшипників з литої бронзи, коли при високих швидкостях обертання рідке мастило стає неефективним. У зв'язку з цим при друкуванні накладу 8-10 тис. фарбовідбитків кількість бракованих відбитків складала близько 400-500 відбитків, що відповідає близько 5 \% браку продукції (рис. 4).

Втім при встановленні у друкарську машину KBA Rapida-105 деталей тертя на основі нікелевого сплаву ЭИ 929- $\mathrm{CaF}_{2}$ та на основі міді ДН5МЗКФ9, оброблених за новими технологіями надтонкого абразивного оброблення (рис. 4), при друкуванні такого ж за обсягом накладу кількість бракованих відбитків складала 220-300 відбитків, що становить 2,8-3,0 \% браку продукції. Це пов'язано з більшою рівномірністю суміщення фарб та зменшення розтискування, що, 

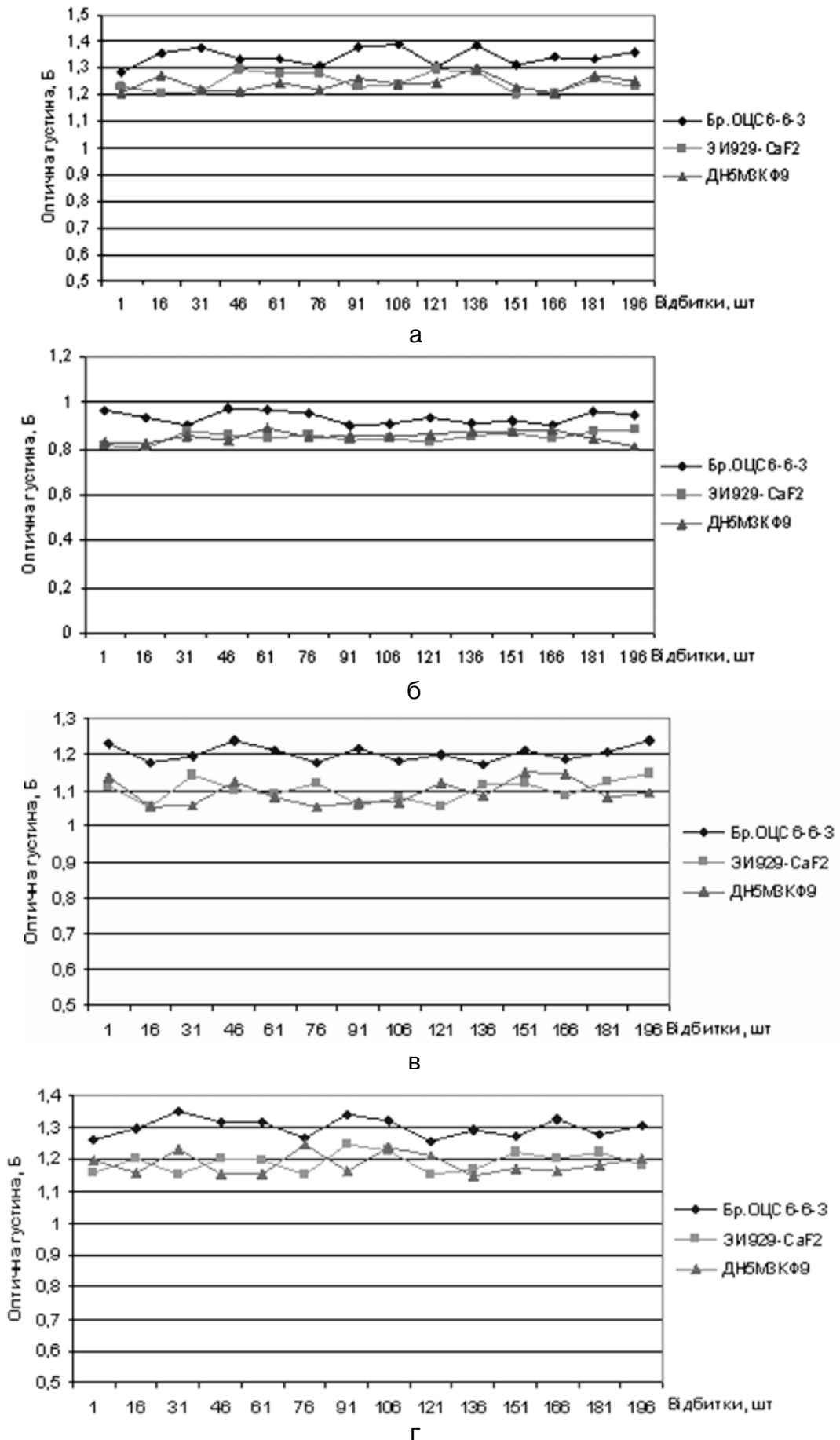

Рис. 2. Розподіл оптичної густини на відбитках на офсетному папері масою 80 г/м²: а - чорна фарба; б - жовта фарба; в - пурпурна фарба; г - блакитна фарба 


\section{МАШИНИ I АВТОМАТИЗОВАНІ КОМПЛЕКСИ}
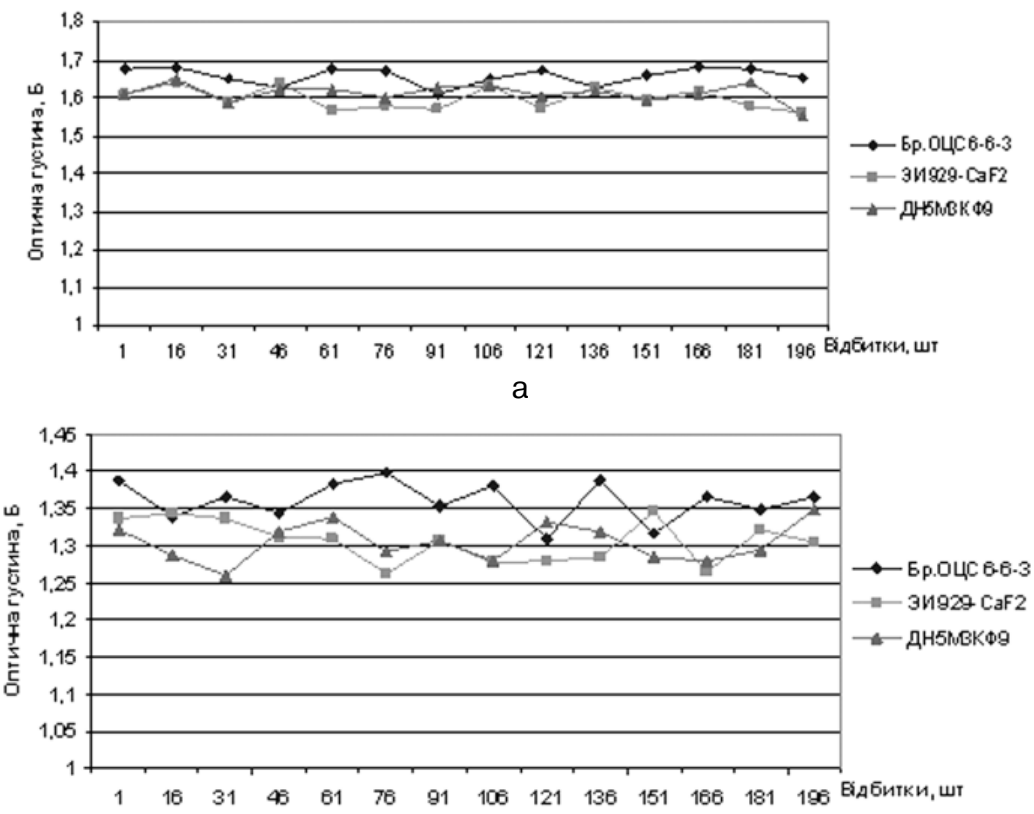

б

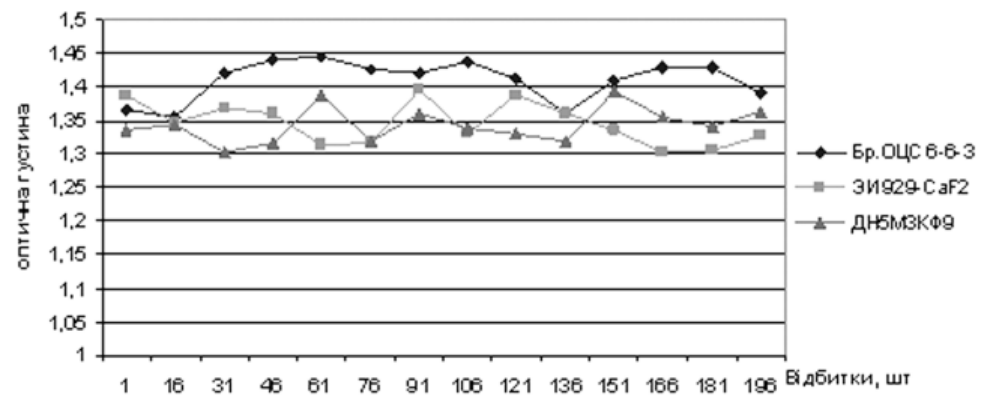

B

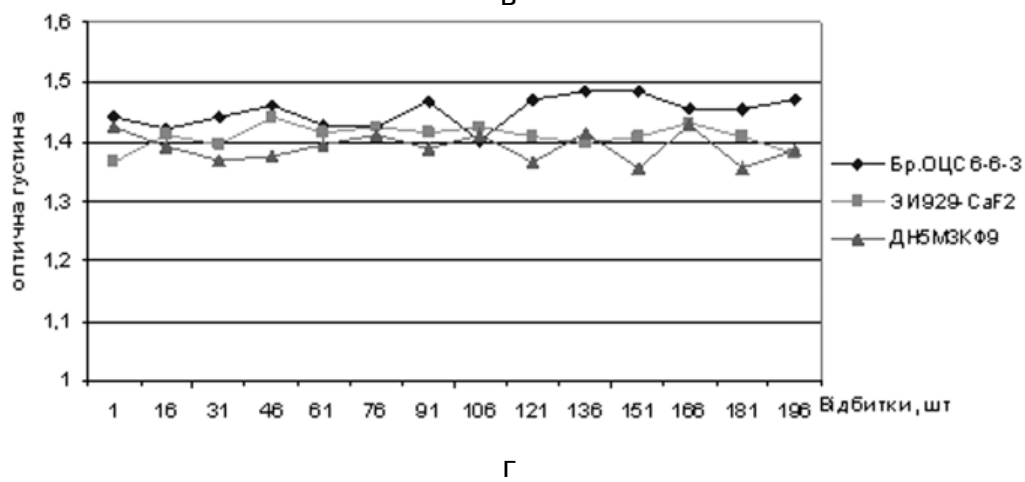

Рис. 3. Розподіл оптичної густини на відбитках на крейдованому папері 115 г/м²: а - чорна фарба; б - жовта фарба; в - пурпурна фарба; г - блакитна фарба 
у свою чергу, є наслідком зменшення биття валів у зв'язку 3 суттєвим підвищенням стабільності роботи вузла за рахунок ефекту самозмащування (в наслідок наявності у складі твердого мастила) механічно оброблених за новими технологіями деталей тертя на основі нікелево- го сплаву ЭИ 929- $\mathrm{CaF}_{2}$ та на основі міді ДН5МЗКФ9.

\section{Висновки}

Одержані дані свідчать про ефективність застосування у вузлах друкарських машин підшипників на основі нікелевого сплаву ЭИ 929- $\mathrm{CaF}_{2}$ та на ос-

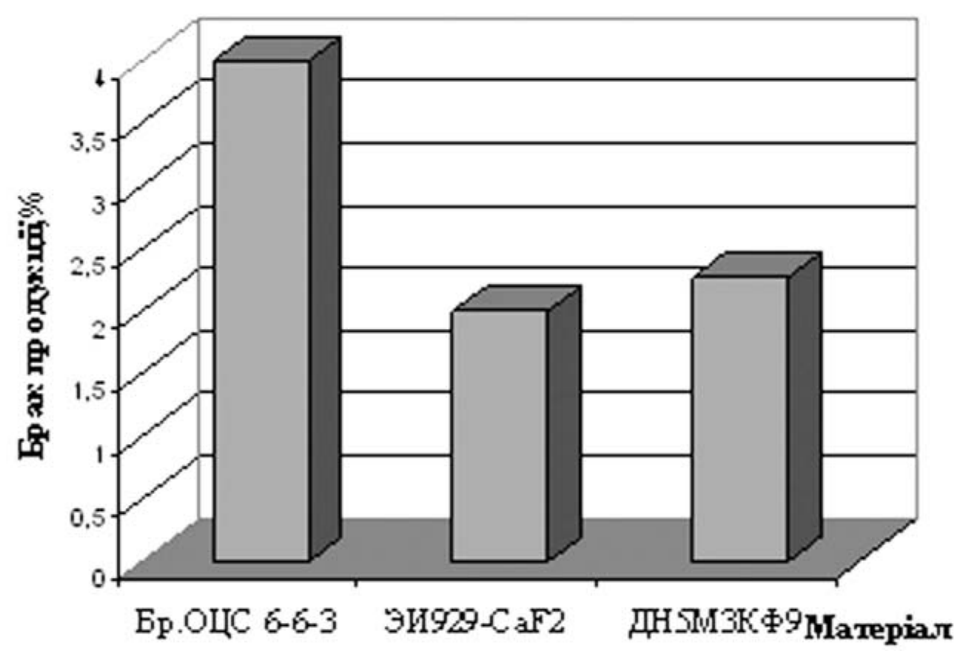

a

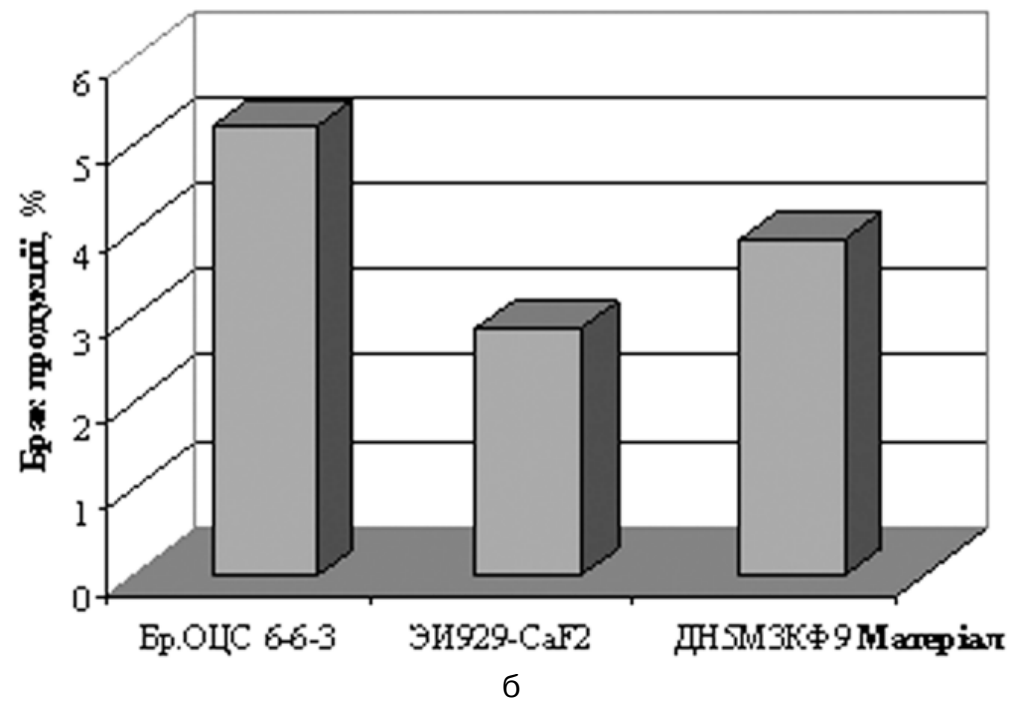

Рис. 4. Якість продукції при друкуванні на друкарській машині КВА Rapida-105 з використанням у вузлах базових та досліджуваних деталей: a - офсетний папір; б - крейдований папір 


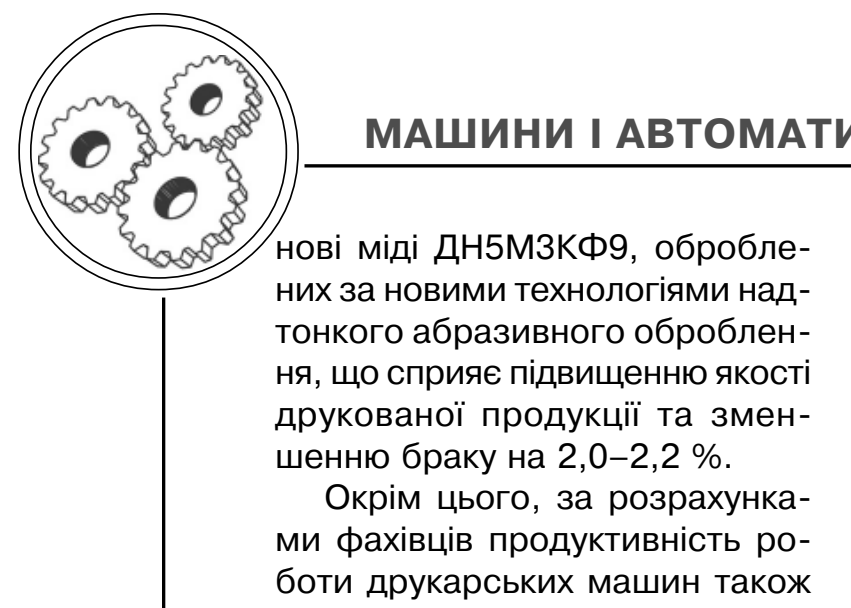

\begin{abstract}
підвищується завдяки зменшенню часу на профілактику, діагностику і технічне обслуговування робочих органів, що сприяє збільшенню кількості замовлень та підвищенню загального обсягу виробництва поліграфічної продукції на 1633,3-1422,2 тис. фарбо-відбитків на рік.
\end{abstract}

1. Роїк Т. А. Композиційні підшипникові матеріали для підвищених умов експлуатації : Монографія / Т. А. Роїк, П. О. Киричок, А. П. Гавриш. - К. : НТУУ «КП|», 2007. - 404 с. 2. Гавриш А. П. Сучасні можливості магнітоабразивним обробленням важкооброблюваних матеріалів / А. П. Гавриш, О. О. Мельник // Вісник Київського Національного університету технології та дизайну. - 2008. - № 3(41). - С. 22-28. 3. Мельник О. О. Магнітноабразивна обробка важко навантажених підшипників ковзання / О. О. Мельник, Ю. Ю. Віцюк, А. П. Гавриш, Т. А. Роїк // Тези доповідей Загально університетської науково-технічної конференції молодих вчених та студентів, присвяченої дню Науки. - 4. 2. - Секція «Машинобудування». - Підсекція «Технологія машинобудування», 2010. - С. 33-34. 4. Мельник О. О. Вплив технології виготовлення та магнітно-абразивної обробки на властивості високошвидкісних підшипників / О. О. Мельник, Ю. Ю. Віцюк, А. П. Гавриш, Т. А. Роїк // Тези доповідей XI Міжнародної науково-технічної конференції «Прогресивна техніка і технологія-2010», присвяченої 100-річчю від дня народження акад. НАН України Г. С. Писаренка, м. Київ. НТУУ «КПІ», 18-21 травня 2010. - С. 91.

\author{
Рецензент - П. О. Киричок, д.т.н., \\ професор, НТУу «КП।»
}

